\title{
Nutritional components and physiological activities of Petasites japonicus solvent extracts
}

\author{
Hyun-Ju Eom ${ }^{1 \ddagger}$, Hyun Young Shin ${ }^{2 \ddagger}$, Yu Yeong Jeong ${ }^{1}$, Nu Ri Kwon ${ }^{1}$, \\ Ki Hyun $\mathrm{Kim}^{1}$, In Jae $\mathrm{Kim}^{1}$, Kwang-Won $\mathrm{Yu}^{3 *}$ \\ ${ }^{1}$ Chungcheongbukdo Agricultural Research and Extension Services, Cheongju 28130, Korea \\ ${ }^{2}$ Transdisciplinary Major in Learning Health System, Department of Integrated Biomedical and Life Science, \\ Graduate School, Korea University, Seoul 02841, Korea \\ ${ }^{3}$ Major in Food and Nutrition, Korea National University of Transportation, Jeungpyeong 27909, Korea
}

\section{머위(Petasites japonicus)의 영양성분 및 추출물을 이용한 생리활성}

\author{
엄현주 $^{\ddagger} \cdot$ 신현영 $^{2 \ddagger} \cdot$ 정유영 ${ }^{1} \cdot$ 권누리 $^{1} \cdot$ 김기현 $^{1} \cdot$ 김인재 $^{1} \cdot$ 유광원 $^{3 *}$ \\ 1충청북도농업기술원, ${ }^{2}$ 고려대학교 대학원 의생명융합과학과 러닝헬스시스템융합전공, \\ 3한국교통대학교 식품영양학전공
}

\begin{abstract}
Petasites japonicus (PJ) has been used traditionally as the treatment or the prophylaxis of migraine and tension headache in Asia. In the present study, to we compared the characteristics of PJ powder and extracts obtained by various methods utilize the PJ as a functional material. PJ powder by freeze-drying possessed $6.61 \%$ water content, $4.51 \%$ crude fat, $23.75 \%$ crude protein, $18.62 \%$ crude ash, $46.97 \%$ carbohydrates, and crude fiber $39.22 \%$. It contained a particularly high potassium content in mineral. Among different extraction methods, extracts of $50 \%$ (PJ-50E) or $70 \%$ ethanol (PJ-70E) showed the highest total polyphenol content and antioxidant activity, while cold-water extraction (PJ-WE) showed the lowest. However, when the $\alpha$-glucosidase inhibitory were analyzed, PJ-WE was highest while the treatment extracted ethanol were not active at all. In anti-inflammatory activity by RAW 264.7 and HaCaT cells, PJ-WE showed significantly higher inhibitory activity in comparison to those of the other extract. In conclusion, it is considered that the water-extraction method is better than other extraction methods for practical preparation of functional materials with high a-glucosidase inhibitory and anti-inflammatory activities from PJ.
\end{abstract}

Keywords : Petasites japonicus, solvent extract, nutritional components, physiological activity

서 론

머위(Petasites japonicus)는 주로 야산의 습지에서 자생하 는 국화과에 속하는 다년생 초본식물로서, 중국, 일본뿐만 아 니라 우리나라의 경우 제주도에서부터 중부지방까지 전역에
서 자생하고 있다(Oh 등, 2006). 머위는 머우, 머구 등 지역 마다 부르는 이름도 다양하며, 잎과 줄기는 쌈채소나 장아찌 로 식용하고, 꽃과 뿌리는 약재로 쓰이는 등 버릴 것이 없는 우리나라 대표적인 산채이다(Cho 등, 2006). 한방에서는 거담, 진해 등을 치료하는 한약재로 쓰였고, 민간에서도 이와 비슷한

*Corresponding author. E-mail : kwyu@ut.ac.kr, Phone :+82-43-820-5333, Fax : +82-43-820-5850

${ }^{\ddagger}$ These authors contributed equally to this work.

Received 28 September 2021; Revised 02 November 2021; Accepted 04 November 2021.

Copyright (c) The Korean Society of Food Preservation.

This is an Open Access article distributed under the terms of the Creative Commons Attribution Non-Commercial License (http://creativecommons.org/licenses/by-nc/4.0) which permits unrestricted non-commercial use, distribution, and reproduction in any medium, provided the original work is properly cited. 
이유로 감기, 편도선염 등과 관련되어 오랫동안 애용하여 왔다 (Seo 등, 2008). 다만, 유독 성분(pyrrolizidine alkaloids)이 다 소 존재하여 생으로 먹기보다는 꼭 소금물에 데쳐서 익혀서 먹어야 한다(Lee, 2013). 머위에 존재하는 다양한 유효성분 중 꽃에는 caffeic acid, 3-O-caffeoylquinic acid, fukinolic acid 등의 항산화물질이 검출되었고(Hiemori-Kondo과 Nii, 2020), 잎에는 petasin, $S$-petasin 등의 sesquiterpene ester류 가 항천식이나 항알러지 효능이 있는 것으로 보고되고 있으 며(Thomet 등, 2001), 최근에는 잎에서 항알러지 및 항염에 효과가 있는 backkenolide B(Lee 등, 2013)나 petatewalide $\mathrm{B}$ (Choi 등, 2016) 등과 같은 물질이 분리, 동정되고 있다. 앞 에서 열거한 머위의 유효물질에 의해 다양한 기능성 관련 선 행연구가 수행되었는데, 머위 $70 \%$ 에탄올 추출물에서 항산 화 및 항염증 효과 연구(Kim 등, 2006), 머위 잎자루에서 항 산화물질인 kaempferol를 분리한 연구(Kim 등, 2008), 머위 열수 및 에탄올 추출을 통한 항산화와 항암활성 연구(Seo 등, 2008) 등이 있다. 또한, Wang 등(2014)은 머위 분획물의 라디 칼 소거능 및 신경세포의 산화적 스트레스 보호 효과를 알아 보았으며, Kim 등(2020)은 LPS로 염증을 유도한 마우스 대 식세포에 머위 잎의 열수 추출물을 처리하였을 때, NO 및 $\mathrm{ROS}$ 수준을 억제하여 항염 효과가 있음을 보고하였다. 이렇 듯 다양한 기능성 물질과 효능을 가지고 있음에도 불구하고 머위를 활용하여 제품을 개발한 사례는 부족한데, $0.75 \%$ 머 위분말을 첨가하여 생면제조 시 기호도와 기능성이 우수하였 음을 보고한 연구(Lee, 2011), 데침과 해동하는 방법에 따른 머위대의 품질을 조사한 연구(Lee 등, 2015), 머위, 수세미 및 어성초를 혼합하여 음료를 제조하였을 때, 머위 함량이 증가 할수록 항알러지활성이 높다고 보고하였고(Jeong, 2016), 동 결건조한 머위 분말을 활용하여 쿠키를 제조할 경우 쌀가루 함량에 $10 \%$ 머위를 첨가한 것이 기호도와 기능성이 우수하 였다고 보고(Choi와 $\mathrm{Sim}, 2021)$ 한 것이 거의 전부이다.

따라서, 본 연구에서는 다양한 기능성이 보고되고 있는 머 위의 소비확대를 위하여 조섬유를 포함하는 일반성분과 무기 질을 분석하고, 물(냉수, 열수) 및 에탄올(50\%와 $70 \%)$ 추출 물을 조제한 후 항산화활성 및 항염증 활성을 분석하여 농가 의 신소득 작목이나 기능성 식품 소재로의 기초자료를 제공 하고자 하였다.

\section{재료 및 방법}

\section{실험 재료 및 전처리}

본 연구에서 사용된 머위는 2021년 3월 충청북도농업기술 원 특작시험 포장 하우스에서 재배중인 것을 사용하였고, 머 위 잎과 줄기를 세척한 후 동결건조(PVTFD 30R, Ilshin, Dongducheon, Korea)하였다. 머위의 일반성분과 무기질은
동결건조 된 시료를 사용하였고, 나머지 실험은 상온, 열수, $50 \%$ 및 $70 \%$ ethanol 추출한 뒤 분석하였다. 동결건조한 머 위에 20 배 $(\mathrm{w} / \mathrm{v})$ 중량의 증류수를 가하고 48 시간 동안 상온에 서 침지하여 추출하였다(water extract of P. japonicus, $\mathrm{PJ}-\mathrm{WE})$. 열수 추출의 경우, 머위 중량의 20 배(w/v) 해당하는 증류수를 가하고 4시간 동안 decoction 하여 추출하였다(hot water extract of $P$. japonicus, PJ-HWE). 50\%(50\% ethanol extract of $P$. japonicus, $\mathrm{PJ}-50 \mathrm{E})$ 와 $70 \%$ ethanol( $70 \%$ ethanol extract of P. japonicus, PJ-70E) 추출은 머위 무게의 20 배 $(\mathrm{w} / \mathrm{v})$ 에 해당하는 용매를 첨가하고 48 시간 동안 상온에서 침 지하여 추출하였다. 각각의 추출물을 거즈로 1 차 여과, ADVANTEC paper를 이용하여 2차 여과하였다. 여과된 추 출물을 $40^{\circ} \mathrm{C}$ water bath(BS-21, Lab Companion, Jeiotech, Daejeon, Korea)에서 6-12 ${ }^{\circ} \mathrm{Brix}$ 가 되도록 감압 농축한 뒤, 소분하여 48시간 동안 동결건조한 후 실험에 사용하였다.

\section{일반성분 분석}

동결건조한 머위의 일반성분 분석은 $\mathrm{AOAC}$ 방법(1990)에 따라 측정하였다. 수분 함량은 $105^{\circ} \mathrm{C}$ 상압가열건조법, 조단 백질은 Micro-Kjeldahl, 조지방은 Soxhlet 추출법, 조회분의 함량은 $550^{\circ} \mathrm{C}$ 직접회화법을 사용하였고, 추가적으로 조섬유 를 측정하였는데, Fibertec system M(Tecator Co., Hoganas, Sweden)을 이용하여 Henneberg-Stohmann 개량법으로 분석 하였다. 탄수화물의 함량은 $100 \%$ 에 수분, 조단백질, 조지방, 조회분의 함량을 뺀 값으로 정의하였다.

\section{무기질 성분 분석}

동결건조한 머위의 무기질 분석은 Osborne과 Voogt(1981) 의 방법에 따라 마이크로웨이브 분해기(Ultrawave, Milestone, Italy)로 시료를 분해 및 냉각한 후 $50 \mathrm{~mL}$ 정용 플라스크로 옮겨서 증류수로 정용하였다. 구리 $(\mathrm{Cu})$ 를 제외한 8 가지 무기 성분( $\mathrm{Al}, \mathrm{Ca}, \mathrm{Fe}, \mathrm{K}, \mathrm{Mg}, \mathrm{Mn}, \mathrm{Na}, \mathrm{Zn})$ 은 ICP-OES(Agilent 720 -ES, Australia)로 분석하여 각각의 무기성분 함량을 구하 였다. 분석조건은 power는 $1.20 \mathrm{kw}$, analysis pump rate는 15 $\mathrm{rpm}$, rinse time은 $10 \mathrm{sec}$ 로 하였다. 구리는 ICP-MS(Analytik Jena Aurora Elite, Germany)를 이용하였고, 분석조건은 power $1.45 \mathrm{kw}$, analysis pump rate $10 \mathrm{rpm}$, rinse time은 10 $\mathrm{sec}$ 로 하였다.

\section{총폴리페놀 함량 측정}

추출용매별 머위의 총폴리페놀 함량은 Folin-Ciocalteu's 방법에 따라 분석하였다(Jang 등, 2012). 각 추출액 $100 \mu \mathrm{L}$ 에 $2 \% \mathrm{Na}_{2} \mathrm{CO}_{3}$ 용액 $2 \mathrm{~mL}$ 를 가하고 3분 방치한 후 $50 \% \mathrm{~F}-\mathrm{C}$ reagent $100 \mu \mathrm{L}$ 를 가하였다. 30 분 후 반응액의 흡광도 값을 
$750 \mathrm{~nm}$ 에서 측정하였고 표준물질로 $0.1 \%$ gallic acid를 사용 하였다.

\section{자유라디칼 소거능 측정}

추출용매별 머위의 자유라디칼 소거능은 ABTS 라디칼 소 거능 및 $\mathrm{DPPH}$ 라디칼 소거능으로 측정하였다. 2,2'-azino3-ethylbenzothiazoline-6-sulfonic acid(ABTS) 라디칼 제거 활성은 Choi 등(2006)의 방법에 따라 측정하였다. ABTS 라 디칼 소거능은 $2.45 \mathrm{mM}$ potassium persulfate와 $7 \mathrm{mM} \mathrm{ABTS}$ 혼합물을 실온조건의 암소에서 24시간 방치하여 ABTS 양이 온을 형성시킨 후, 증류수로 희석하여 $735 \mathrm{~nm}$ 에서 흡광도가 1.4-1.5가 되도록 한다. 희석된 ABTS 용액 $1 \mathrm{~mL}$ 에 시료추출 물 $50 \mu \mathrm{L}$ 를 가하여 30 분간 반응시켜 $735 \mathrm{~nm}$ 에서 흡광도를 측정하였다. ABTS 라디칼의 소거능은 시료 첨가구와 시료 를 첨가하지 않은 경우의 흡광도를 백분율(\%)로 나타내었다. 추출용매별 머위의 1,1-diphenyl-2-picrylhydrazyl(DPPH) 라 디칼 소거능은 $0.4 \mathrm{mM} \mathrm{DPPH(Sigma-Aldrich,} \mathrm{St.} \mathrm{Louis,}$ $\mathrm{MO}, \mathrm{USA}$ ) 용액을 흡광도 값이 1.3-1.4가 되도록 희석한 후 추출물 $0.2 \mathrm{~mL}$ 에 $\mathrm{DPPH}$ 용액 $0.8 \mathrm{~mL}$ 를 가한 후 실온에서 30 분간 방치 후 $525 \mathrm{~nm}$ 에서 흡광도를 측정하였다. 이때 전 자공여능은 시료 첨가구와 비첨가구의 흡광도 차이를 백분율 (\%)로 나타내었다(Choi 등, 2003).

\section{$\alpha$-Glucosidase 저해활성 분석}

추출용매별 머위의 $\alpha$-glucosidase 저해활성은 Tibbot과 Skadsen(1996) 방법을 참고하여 측정하였다. $1.5 \mathrm{mM} \mathrm{p}$ nitrophenol- $\alpha$-D-glucopyranoside( $p$ NPG, Sigma-Aldrich Co., Darmstadt, Germany) $50 \mu \mathrm{L}$ 와 $3.5 \mathrm{unit} / \mathrm{mL} \alpha$-glucosidase 효 소액 $100 \mu \mathrm{L}$ 를 혼합하고, 대조구에는 증류수 $50 \mu \mathrm{L}$ 와 처리 구에는 여과한 시료 $50 \mu \mathrm{L}$ 를 넣어 발색시켰다. 이때 생성된 $p$-nitrophenol( $p$ NP, Sigma-Aldrich Co., Darmstadt, Germany) 는 $405 \mathrm{~nm}$ 에서 분광광도계로 흡광도를 측정하여 대조구에 대한 흡광도 감소 정도를 백분율로 표현하였으며, 양성대조 구로 $10 \mathrm{mg} / \mathrm{mL}$ acarbose(Sigma-Aldrich Co., Darmstadt, Germany)를 사용하였다.

\section{면역세포를 이용한 염증억제활성 분석}

마우스 유래 대식세포주인 RAW 264.7은 한국세포주은행 (Korean Cell Line Bank; KCLB, Seoul, Korea)에서 입수하 였으며, 세포주는 $10 \%$ fatal bovine serum(FBS; Gibco, Waltham, Massachusetts, USA)와 1\% penicillin-streptomycin (P/S; GenDEPOT, Katy, TX, USA)이 첨가된 Dulbecco's Modified Eagle Medium(DMEM; HyClone, San Angelo, TX, USA) 배지에서 배양하였다. RAW 264.7의 염증억제활
성 평가를 위해 RAW 264.7 세포를 $3 \times 10^{5} \mathrm{cells} / \mathrm{mL}$ 로 조정 한 후 96 well plate에 $200 \mu \mathrm{L}$ 씩 도포하고 배양기에서 약 18시 간 동안 배양하였다. 이후 배양 상등액을 모두 제거하고 FBS가 함유되지 않은 serum free-DMEM(SFM) $160 \mu \mathrm{L}$ 와 시료 20 $\mu \mathrm{L}$ 를 첨가하여 배양하였다. 30 분 후 염증 유발 물질로 10 $\mu \mathrm{g} / \mathrm{mL}$ 의 lipopolysaccharide from Escherichia coli(LPS: SigmaAldrich) $20 \mu \mathrm{L}$ 를 첨가한 다음 24 시간 동안 재배양하였다. LPS 로 염증이 유발된 RAW 264.7 세포에서 시료에 의한 독성평가 는 3-(4,5-dimethylthiazol-2-yl)-2,5-diphenyltetrazolium bromide (MTT; Invitrogen, Eugene, OR, USA)법을 통해 $550 \mathrm{~nm}$ 의 흡광도에서 측정하였으며, LPS 유도군에 대한 세포생존율 (cell viability, \%)로 나타냈다. 한편, 세포에서 분비되는 사이 토카인인 interleukin-6(IL-6)는 BD Bioscience(San Diego, CA, USA)에서 구입한 enzyme-linkage immunosorbent assay (ELISA kit)를 통해 분석하였으며, 제조사에서 제공된 standard reference를 이용하여 작성된 표준곡선을 통해 함량을 계산하 였다. 또한, 산화질소(nitric oxide, $\mathrm{NO}$ )의 함량은 griess assay 를 통해 측정하였고 sodium nitrate $\left(\mathrm{NaNO}_{3}\right)$ 를 이용하여 표준 곡선을 작성하여 $\mu \mathrm{M}$ 로 함량을 평가하였다.

\section{피부세포주를 이용한 피부염 억제활성 분석}

인간유래 각질형성 세포주인 $\mathrm{HaCaT}$ keratinocyte를 한국 세포주은행(Korean Cell Line Bank, KCLB; Seoul, Korea)에 서 입수하였으며, 상기 배지와 동일한 조성으로 구성된 배지 를 이용하여 배양하였다. 피부염 억제활성은 $\mathrm{HaCaT}$ 세포에 $\mathrm{TNF}-\alpha$ 및 interferon-gamma(IFN- $\gamma$ )를 처리함으로써, 염증 모델을 형성한 후 세포에서 분비되는 IL-6 및 interleukin-8 (IL-8)의 함량을 평가하였다. $\mathrm{HaCaT}$ 세포는 $1 \times 10^{5}$ cells $/ \mathrm{mL}$ 로 조정한 후 plate에 $200 \mu \mathrm{L}$ 씩 도포하고 배양기에서 약 24 시간 동안 배양하였다. 이후 배양 상등액을 모두 제거하고 SFM $160 \mu \mathrm{L}$ 와 시료 $20 \mu \mathrm{L}$ 를 첨가하고 배양하였으며, 1 시간 후 염증 유발 물질로 각각 $10 \mathrm{ng} / \mathrm{mL}$ 의 TNF- $\alpha$ 와 IFN- $\gamma(\mathrm{T}+\mathrm{I})$ 가 혼합된 용액 $20 \mu \mathrm{L}$ 를 첨가한 후 24 시간 동안 재배양하였 다. $\mathrm{T}+\mathrm{I}$ 로 염증모델을 형성한 $\mathrm{HaCaT}$ 세포에서 시료에 의한 독성평가는 상기 언급된 MTT법으로 측정하였으며, 세포로 부터 분비된 염증성 사이토카인인 IL-6 및 IL-8의 함량은 BD Biosciences에서 구입한 ELISA kit를 이용하여 측정하였다. IL-6 및 IL-8의 생성량은 제조사에서 제공하는 recombinant protein을 이용하여 작성된 표준곡선을 통해 함량으로 계산 되었다.

\section{통계처리}

무기질 분석을 제외한 모든 시험은 3번 반복하여 실시하였 으며, 결과는 평균 \pm 표준편차(standard deviation, SD)로 나타냈 
다. 세포주를 통한 염증 억제할성은 SPSS(Statistical Package for the Social Science, Ver 26 SPSS INC. Chicago, USA)를 이용한 Student's t-test로 계산하였으며 각각 $\mathrm{p}<0.05, \mathrm{p}<0.01$, $\mathrm{p}<0.001$ 수준에서 유도군과의 유의성을 검증하였다. 한편, 총폴리페놀 함량, 라디칼 소거능 및 $\alpha$-glucosidase inhibitory 의 경우 분산의 동질성을 비교하기 위해 Levene's test를 실 시하고, 동질성을 갖는 경우 분산분석(ANOVA)을 실시한 후 측정값 간의 유의성을 Duncan's multiple range test로 $\mathrm{p}<0.05$ 수준에서 검증하였다.

\section{결과 및 고찰}

\section{머위의 일반성분}

동결건조한 머위의 일반성분은 Table 1 에 나타내었다. 분 석에 사용한 머위는 동결건조 한 뒤 마쇄하여 분말형태로 사 용하였으며, 함량은 모두 \% 단위로 나타내었다. 그 결과, 수 분함량 $6.61 \%$, 조지방 $4.51 \%$, 조단백질 $23.75 \%$, 조회분 $23.75 \%$, 탄수화물 $46.97 \%$ 및 식이섬유 $39.22 \%$ 로 검출되었 다. Cho 등(2006)의 연구에 따르면 음건한 머위 잎과 줄기에 서 수분함량, 조단백질 및 탄수화물의 함량이 크게 달랐는데, 특히 잎에서 조단백질이 $29.44 \%$ 로 줄기(11.68\%)보다 높게 검출되었고, 탄수화물은 반대로 줄기에서 $42.82 \%$ 로 $37.97 \%$ 잎보다는 높게 검출되었으나 이것은 서로 다른 수분함량 차 이(잎 $16.53 \%$ : 줄기 $26.39 \%$ )에 기인한 것으로 판단된다. 본 연구에서의 수분함량은 $6.16 \%$ 로서 앞의 선행연구보다 약 4-5배 적게 검출되었는데, 서로 다른 수분함량의 차이에도 불구하고, 조지방과 조회분은 본 연구결과가 높게 검출되었 다. 건조방법별 취나물(Jiang 등, 2016)의 수분을 측정하였을 때 천일건조 $12.36 \%, 500^{\circ} \mathrm{C}$ 열풍건조 $10.20 \%$ 및 동결건조 $6.14 \%$ 로 본 연구결과 동결건조 머위 잎의 수분함량 $6.16 \%$ 와 동일한 결과를 나타냈다.

농촌진흥청 국가표준식품성분표(RDA, 2020)의 데친 머 위, 말린 머위, 삶아서 말린 머위, 삶은 머위, 생 머위에 대한 일반성분에 대한 분석결과에 따르면, 건조하지 않은 생 머위 는 수분 $93.5 \%$, 조지방 $0.14 \%$, 조단백질 $2.31 \%$, 조회분 $1.31 \%$, 탄수화물 $2.74 \%$, 식이섬유 $2.7 \%$ 로 분석되었다. 데친 머위와 삶은 머위는 탄수화물과 식이섬유를 제외하고 생 머 위와 유사한 경향을 보였다. 말린 머위의 경우 식이섬유를 제 외하고 수분 $7.2 \%$, 조지방 $3.7 \%$, 조단백질 $17.4 \%$, 조회분
$13.5 \%$, 탄수화물 $58.2 \%$ 로 분석되었다. 다음으로 삶아서 말린 머위는 수분 $8.3 \%$, 조지방 $4.67 \%$, 조단백질 $26.73 \%$, 조회분 $11.68 \%$, 탄수화물 $48.62 \%$ 및 식이섬유 $39.1 \%$ 로 분석되었다. 본 연구결과와 비교하였을 때, 동결건조한 머위의 수분이 가 장 낮게 검출된 반면 조회분이 높게 검출되었으며, 삶아서 말 린 머위와 조단백질, 조지방, 탄수화물, 식이섬유는 유사한 경 향성을 보였다. 비슷한 종류의 취나물(참취, 삶아서 말린 것)은 수분 $5.4 \%$, 조지방 $3.67 \%$, 조단백질 $26.85 \%$, 조회분 $7.26 \%$, 탄수화물 $56.82 \%$ 및 식이섬유 $38.5 \%$ 로 분석되었는데, 본 연 구의 머위와 비교했을 때 조회분을 제외하고는 비슷한 함량 을 보였다. 일반적으로 머위는 생으로 먹는 경우가 많으나 다 양한 가공품 개발을 위해서는 열풍, 냉풍 등 다양한 방법으로 건조한 것에 대한 영양성분의 업데이트가 필요할 것으로 판 단된다.

\section{머위의 무기질 성분}

동결건조한 머위의 무기질 성분은 Table 2 와 같으며, $\mathrm{K}$ (칼 륨), $\mathrm{Ca}$ (칼슘), $\mathrm{Mg}$ (마그네슘)이 $5,120.72 \mathrm{mg} / 100 \mathrm{~g}, 1,487.52$ $\mathrm{mg} / 100 \mathrm{~g}, 367.14 \mathrm{mg} / 100 \mathrm{~g}$ 으로 비교적 높게 검출되었다. 다 음으로 $\mathrm{Na}$ (나트륨) $67.14 \mathrm{mg} / 100 \mathrm{~g}, \mathrm{Fe}$ (철) $6.22 \mathrm{mg} / 100 \mathrm{~g}$, $\mathrm{Al}$ (알루미늄) $4.57 \mathrm{mg} / 100 \mathrm{~g}, \mathrm{Zn}$ (아연) $2.82 \mathrm{mg} / 100 \mathrm{~g}, \mathrm{Cu}$ (구리) $1.62 \mathrm{mg} / 100 \mathrm{~g}, \mathrm{Mn}$ (망간) $1.81 \mathrm{mg} / 100 \mathrm{~g}$ 순으로 분석 되었다. 국가표준식품성분표(RDA, 2020)에 따르면 말린 머 위의 무기질성분 분석결과 $\mathrm{Mg}, \mathrm{Zn}, \mathrm{Cu}$ 및 $\mathrm{Mn}$ 은 불검출되었 고, $\mathrm{Ca} 1,104 \mathrm{mg} / 100 \mathrm{~g}, \mathrm{Fe} 59 \mathrm{mg} / 100 \mathrm{~g}, \mathrm{~K} 1,114 \mathrm{mg} / 100$ $\mathrm{g}, \mathrm{Na} 48 \mathrm{mg} / 100 \mathrm{~g}$ 으로 검출되었다. 또 다른 결과인 삶아서 말린 머위의 경우도 $\mathrm{K}, \mathrm{Ca}$ 순으로 높은 함량을 보였는데, $3,552 \mathrm{mg} / 100 \mathrm{~g}$ 및 $1,253 \mathrm{mg} / 100 \mathrm{~g}$ 으로 본 연구결과와 함량 의 차이는 있으나 경향성은 유사하였다. 본 연구결과와 비교 하였을 때, 말린 머위와 삶아서 말린 머위의 $\mathrm{Fe}, \mathrm{Mn}$ 를 제외 하고 모두 동결건조한 머위의 무기질 함량이 높은 것으로 나 타났다. 특히, 무기질 중 $\mathrm{K}$ 의 함량이 높게 나타났는데, 취나 물(참취, 삶아서 말린 것) $2,441 \mathrm{mg} / 100 \mathrm{~g}$, 고추잎(말린 것) $3,780 \mathrm{mg} / 100 \mathrm{~g}$ 으로 다른 건조한 잎들에 높은 $\mathrm{K}$ 함량을 보 였으나, 그 중에서도 특히 머위에 다량의 $\mathrm{K}$ 을 함유하고 있었 다. 무기질 $\mathrm{K}$ 은 세포 내액에 존재하여 신경과 근육의 기능 조절, 삼투압 유지 및 혈액의 산염기의 조절 등의 기능을 가 진 중요한 무기질로, 콩류, 감자류, 과일 및 녹색 채소에 많이 존재하여 부족한 무기질은 아니지만 중요한 무기질 중 하나

Table 1. Proximate composition of $P$. japonicus

(Unit : g/100 g)

\begin{tabular}{ccccccc}
\hline Scientific name & Moisture & Crude protein & Crude lipid & Crude ash & Carbohydrate & Crude fiber \\
\hline$P$. japonicus & $6.16 \pm 0.01^{1)}$ & $23.75 \pm 0.08$ & $4.51 \pm 0.24$ & $23.75 \pm 0.08$ & $46.97 \pm 0.15$ & $39.22 \pm 0.01$ \\
\hline
\end{tabular}

${ }^{1)}$ All values represent mean \pm SD. 
Table 2. Mineral compositions of $P$. japonicus

(Unit: $\mathrm{mg} / 100 \mathrm{~g}$ )

\begin{tabular}{cr}
\hline & P. japonicus \\
\hline $\mathrm{Al}$ & $4.57 \pm 0.03^{1)}$ \\
$\mathrm{Ca}$ & $1,487.52 \pm 1.11$ \\
$\mathrm{Fe}$ & $6.22 \pm 0.37$ \\
$\mathrm{~K}$ & $5,120.72 \pm 1.56$ \\
$\mathrm{Mg}$ & $367.14 \pm 2.57$ \\
$\mathrm{Mn}$ & $1.18 \pm 0.35$ \\
$\mathrm{Na}$ & $67.15 \pm 1.28$ \\
$\mathrm{Zn}$ & $2.82 \pm 0.50$ \\
$\mathrm{Cu}$ & $1.62 \pm 0.34$ \\
\hline $\mathrm{Total}$ & $7,054.37$ \\
\hline
\end{tabular}

${ }^{1)}$ All values represent mean \pm SD.

이다(Song 등 1992). 따라서 건조한 머위를 가공제품 제조 시 첨가하게 되면 무기질 $\mathrm{K}$ 급원식품이 될 수 있는 좋은 식 품 소재로 판단되었다.

\section{머위 추출물의 총폴리페놀 함량 및 라디컬 소거 활성}

추출용매를 달리한 머위 추출물 4종의 총폴리페놀 함량 및 항산화 활성은 Table 3에 나타내었다. 본 실험에서 추출용매 별 머위 추출물의 총폴리페놀 함량은 $50 \%$ 에탄올 추출물 (PJ-50E)일 때, $224.83 \mathrm{mg} / 100 \mathrm{~mL}$ 로 유의적으로 가장 높았 고, $70 \%$ 에탄올 추출물(PJ-70E)이 $211.64 \mathrm{mg} / 100 \mathrm{~mL}$ 로 두 번째로 높게 분석되었다. 상온 추출물(PJ-WE)과 열수 추출 물(PJ-HWE)은 $33.58 \mathrm{mg} / 100 \mathrm{~mL}, 173.24 \mathrm{mg} / 100 \mathrm{~mL}$ 로 유 의적인 차이를 보였다. Lim 등(2008)이 녹차의 총폴리페놀 함량을 분석했을 때, $39.38 \mathrm{mg} / 100 \mathrm{~mL}$ 로 본 연구결과 중 PJ-EW와 PJ-HWE와 유사한 것으로 나타났다. Flavonoids, anthocyanins, tannins, catechins, isoflavones, lignans 등을 총칭하는 폴리페놀 화합물은 식물계에 널리 존재하는 2 차 대 사산물로, phenolic hydroxyl기가 단백질 등의 여러 화합물과 쉽게 결합하는 특성으로 항산화, 항염증 효과 등 다양한 생리 활성이 증가하는 것으로 보고되어(Manach 등, 2004; Urquiaga 과 Leighton, 2000) 머위에 다량의 총폴리페놀을 함유하고 있으며, 특히 에탄올 추출 시 더 높게 검출됨을 알 수 있었다.

다음으로 추출용매별 머위 추출물을 5,000 배 증류수로 희석 하여 $\mathrm{DPPH}$ 라디칼 소거능을 확인하였을 때, $\mathrm{PJ}-70 \mathrm{E}$ 이 $72.01 \%$ 로 유의적으로 높았고, PJ-50E(61.86\%), PJ-HWE(41.24\%), $\mathrm{PJ}-\mathrm{WE}(4.42 \%)$ 순으로 분석되었다. $\mathrm{Kim}$ 등(2012)의 자생식 물 26종과 생약자원 14종을 대상으로 본 연구결과 중 DPPH 라디칼 소거능 활성이 가장 높은 PJ-70E와 비교 - 분석하였 을 때, 자생식물 중 감나무 $(72.87 \%)$, 고사리 $(79.50 \%)$, 비수리 (75.69\%), 윤쇠고비(76.46\%)와 유사한 경향을 나타냈고, 생 약자원 14 종보다 높은 활성을 가지는 것으로 분석되었다. Eom 등(2021)이 60\% ethanol로 추출한 병풀의 DPPH 라디 칼 소거능을 분석한 결과, $27.28 \%$ 로 PJ-WE을 제외한 3종의 추출물이 높은 항산화 활성을 가지는 것으로 나타났다. 국내 9종 산림식물 추출물의 DPPH 라디칼을 분석하였을 때, 까치 밥나무 $(160.79 \mu \mathrm{g} / \mathrm{mL})$, 까마귀머루 $(132.46 \mu \mathrm{g} / \mathrm{mL})$, 다래 $(119.98 \mu \mathrm{g} / \mathrm{mL})$ 순으로 높은 라디칼 소거능을 가지는 것으로 나타나(Sim 등, 2019), 본 연구결과 높은 함량의 항산화능을 가진 것으로 판단된다.

증류수로 10,000 배 희석한 머위 추출액의 $\mathrm{ABTS}^{+}$라디칼 소거능을 분석한 결과는 DPPH 라디칼 소거능 결과와는 다소 차이를 보였으나 총폴리페놀 함량과는 같은 경향성을 보였다. $\mathrm{PJ}-50 \mathrm{E}$ 가 $44.11 \%$ 로 유의적으로 높았고, $\mathrm{PJ}-70 \mathrm{E}(41.40 \%)$, $\mathrm{PJ}-\mathrm{HWE}(27.59 \%), \mathrm{PJ}-\mathrm{WE}(5.02 \%)$ 순으로 유의적으로 감소 하였다. 청미래덩굴의 열수추출물과 $70 \%$ ethanol 추출물의 $\mathrm{ABTS}^{+}$라디칼 소거능을 분석하였을 때, 각각 $500 \mu \mathrm{g} / \mathrm{mL}$ 에 서 $75.8 \%$ 와 $73.4 \%$ 의 소거능이 있는 것으로 나타났다(Lee 등, 2014). 경북 약용작물 5 종(홍화자, 향부자, 형개, 위유, 작

Table 3. Total polyphenol contents and physiological activity of $\boldsymbol{P}$. japonicus with different extract methods

\begin{tabular}{cccc}
\hline & $\begin{array}{c}\text { Total polyphenol } \\
(\mathrm{mg} \mathrm{GAE} / 100 \mathrm{~mL})\end{array}$ & $\begin{array}{c}\text { DPPH radical } \\
\text { scavenging activity (\%) }\end{array}$ & $\begin{array}{c}\text { ABTS radical } \\
\text { scavenging activity (\%) }\end{array}$ \\
\hline PJ-WE & $33.58^{1)} \pm 1.02^{\mathrm{d} 2)}$ & $4.42 \pm 0.30^{\mathrm{d}}$ & $5.02 \pm 0.36^{\mathrm{d}}$ \\
PJ-HWE & $173.24 \pm 1.72^{\mathrm{c}}$ & $41.24 \pm 0.28^{\mathrm{c}}$ & $27.59 \pm 0.37^{\mathrm{c}}$ \\
PJ-50E & $224.83 \pm 8.03^{\mathrm{a}}$ & $61.86 \pm 0.92^{\mathrm{b}}$ & $44.11 \pm 0.97^{\mathrm{a}}$ \\
PJ-70E & $211.64 \pm 5.43^{\mathrm{b}}$ & $72.01 \pm 0.42^{\mathrm{a}}$ & $41.40 \pm 0.63^{\mathrm{b}}$ \\
\hline
\end{tabular}

\footnotetext{
${ }^{1)}$ All values represent mean $\pm \mathrm{SD}$.
}

2)a-dValues with different small letters within a column are significantly different by Duncan's multiple range test $(\mathrm{p}<0.05)$.

PJ-WE, water extract of $P$. japonicus; PJ-HWE, hot water extract of $P$. japonicus; PJ-50E, $50 \%$ ethanol extract of $P$. japonicus; PJ-70E, $70 \%$ ethanol extract of $P$. japonicus. GAE, gallic acid equivalent. 
약)의 $\mathrm{ABTS}^{+}$라디칼 소거능을 분석하였을 때, $1.20-25.07 \%$ $(100 \mu \mathrm{g} / \mathrm{mL}), 4.26-77.32 \%(1,000 \mu \mathrm{g} / \mathrm{mL})$ 로 나타났다(Hwang 등, 2011). 또한, 국내산 산채류 34종 물 추출물 중 $100 \mu \mathrm{g} / \mathrm{mL}$ 농도에서 산부추와 잔대를 제외하고 $1.3-53.0 \%$ 의 $\mathrm{ABTS}^{+}$라 디칼 소거능을 가지는 것으로 분석되었다(Lee 등, 2011). Sim 등(2019)은 국내 산림자생 식물 9종 중 까치밥나무(123.12 $\mu \mathrm{g} / \mathrm{mL})$, 말오줌때 $(113.57 \mu \mathrm{g} / \mathrm{mL})$ 순으로 높은 $\mathrm{ABTS}^{+}$라디 칼 소거능을 가지는 것으로 분석되었다.

Lee 등(2013)은 머위 잎으로부터 유용성분인 petasin 추출 의 최적조건을 알아본 결과, 에탄올 농도, 추출하는 속도 및 추출시간의 영향을 받는 것으로 확인되었고 특히, 추출용매 인 에탄올 농도의 영향을 가장 크게 받는 것으로 보고하고 있어, 추후에 추출물에 존재하는 폴리페놀 화합물을 MS 및 $\mathrm{HPLC}$ 를 이용하여 정성 및 정량분석을 통해 항산화활성에 따른 폴리페놀 함량의 상관관계를 밝히는 것이 필요할 것으 로 판단된다.

\section{추출용매별 머위의 $\alpha$-glucosidase 저해활성}

$\alpha$-glucosidase는 소장 점막의 미세응모막에 존재하는 효소 로서 탄수화물의 소화와 흡수에 필수적인 효소이며, 이 효소 의 활성을 저해시킴으로서 체내의 포도당 흡수를 억제시켜 식후 혈당상승을 감소시킬 수 있어 $\alpha$-glucosidase 저해 물질 의 탐색은 매우 유용하다(Standl 등, 1999). 각각의 추출용매 로 얻은 4종의 머위 추출물을 동결건조 한 뒤 그 분말을 $60 \%$ 에탄올로 100 배 희석하여 $\alpha$-glucosidase 저해활성을 검토한 결과(Table 4), 양성대조구인 acarbose $(10 \mathrm{mg} / \mathrm{mL})$ 는 $74.56 \%$ 이었으며 $\mathrm{PJ}-\mathrm{WE}$ 이 $90.66 \%$ 로 가장 높은 $\alpha$-glucosidase 저해 활성을 나타내었으며, $\mathrm{PJ}-\mathrm{HWE}(33.64 \%)$ 이 그 다음 활성을 나타냈으나 에탄올로 추출한 두가지 처리구 PJ-50E 및 PJ-70E는 활성이 없는 것으로 나타났다. Ahn 등(2020)의 보 고에 의하면 머위 추출물에 존재하는 다양한 페놀 및 플라보 노이드 화합물로 인해 항비만 활성이 있으며, 주요 물질은 fukinolic acid나 kaempferol 3-O-(6"-O-acetyl) glucoside 등 이라고 보고하여 혈당강하능의 효과가 있음을 알 수 있다.

본 연구결과에서 4종의 서로 다른 용매로 추출한 머위 추 출물 중 총폴리페놀 함량, $\mathrm{DPPH}$ 라디칼 소거능 및 $\mathrm{ABTS}$ 라디컬 소거능(Table 3) 모두 에탄올로 추출한 PJ-50E 및
PJ-70E 처리구가 높게 측정되었지만, $\alpha$-glucosidase 저해활 성은 반대로 상온(PJ-WE) 및 열수(PJ-HWE)인 물 추출이 높 게 나타나 항산화활성과 $\alpha$-glucosidase 저해활성 사이에 상관 관계가 없는 것으로 판단된다. Xu 등(2010)은 총폴리페놀 함 량과 DPPH 라디칼 소거능이 높을수록 $\alpha$-glucosidase 저해활 성이 높다고 보고하여 본 연구와는 상이한 결과를 보였으나, $\mathrm{Ahn}$ 등(2015)은 다양한 개별 화합물의 조성과 관련이 있어 항상 상관관계가 성립하는 것은 아니라고 보고하여 본 연구 과 유사한 결과를 나타났다. 따라서, 머위를 이용하여 항당뇨 효과를 갖는 기능성 식품을 개발하기 위해서는 물을 이용하 여 추출하는 것이 더 효과적이라 판단된다.

\section{추출용매별 머위의 세포독성 평가}

염증억제 활성은 세포주에 시료를 처리함으로써, 세포에 서 분비되는 염증 매개 인자를 측정하는 방법이다. 시료 처 리에 의해 세포독성을 나타내면 염증 관련 인자의 생산이 감 소되어 이는 억제활성이 나타나는 것으로 판단할 수 있기 때 문에 먼저 시료에 따른 세포독성 여부를 평가하였다. 시료 처리에 의한 RAW 264.7 세포의 독성평가는 Fig. 1(A)에 나 타냈다. 시료 4종은 50-100 $\mu \mathrm{g} / \mathrm{mL}$ 의 농도범위에서 LPS 유 도군 대비 $95 \%$ 세포생존율이 확인되었으며, 비색법을 통한 세포생존율 평가에서 일반적으로 대조군 대비 $80 \%$ 이상의 세포생존율이 확인되면 세포독성이 나타나지 않는다고 판단 하기 때문에(Lopez-Garcia 등, 2014), 상기 농도범위에서 유 의한 세포독성이 나타나지 않는 것으로 판단되었다. 또한, PJ-50E 처리군은 다른 처리군과 달리 $50-100 \mu \mathrm{g} / \mathrm{mL}$ 의 농도 범위에서 통계적으로 유의한 세포증식능(119.6-149.6\%)이 확인되었다. 동일 농도범위에서 $\mathrm{HaCaT}$ keratinocyte의 세포 독성 평가를 진행하였으며(Fig. 1(B)), T+I 유도군 대비 95\% 이상의 세포생존율을 확인할 수 있었다. 한편, RAW 264.7 세 포에서 유의적인 세포증식능이 확인되었던 PJ-50E는 $\mathrm{HaCaT}$ 세포에서는 증식능이 확인되지 않았으며, $50-100 \mu \mathrm{g} / \mathrm{mL}$ 의 농 도범위에서 PJ-CW 처리군(106.7-120.3\%), PJ-HW 처리군 (107.4-112.9\%) 및 PJ-70E 처리군(102.6-103.5\%)은 통계적 으로 유의한 세포증식활성이 나타났다. Kim 등(2020)의 연 구에서 머위 열수추출물에 주정 침전을 통해 조제한 시료를 RAW 264.7 세포에 처리하였을 때, $25-100 \mu \mathrm{g} / \mathrm{mL}$ 의 농도범

Table 4. $\alpha$-Glucosidase inhibitory activity of $P$. japonicus with different extract methods

(Unit: \%)

\begin{tabular}{|c|c|c|c|c|}
\hline Sample & PJ-WE & PJ-HWE & PJ-50E & PJ-70E \\
\hline$\alpha$-Glucosidase inhibitory & $90.66^{1)} \pm 0.34^{\mathrm{a} 2)}$ & $33.64 \pm 10.05^{\mathrm{b}}$ & $-{ }^{c}$ & $-{ }^{c}$ \\
\hline
\end{tabular}


(A)

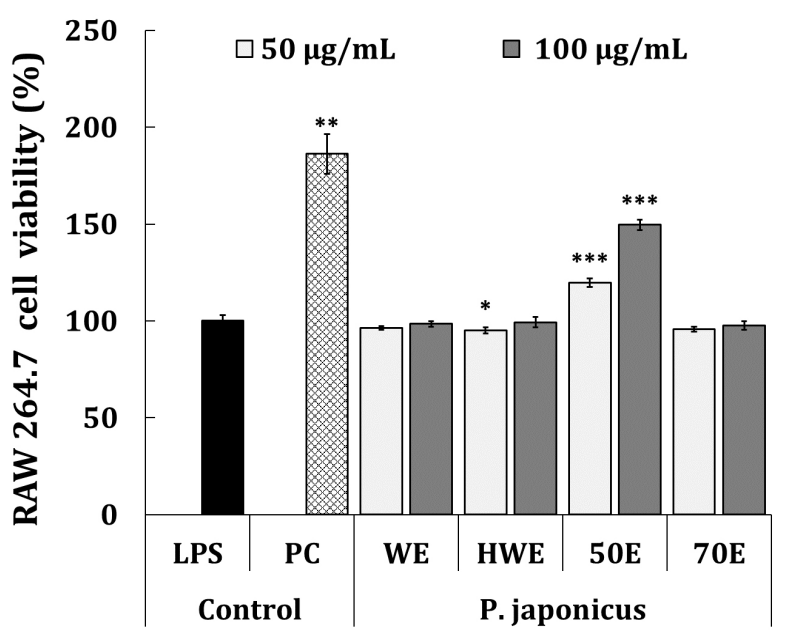

(B)

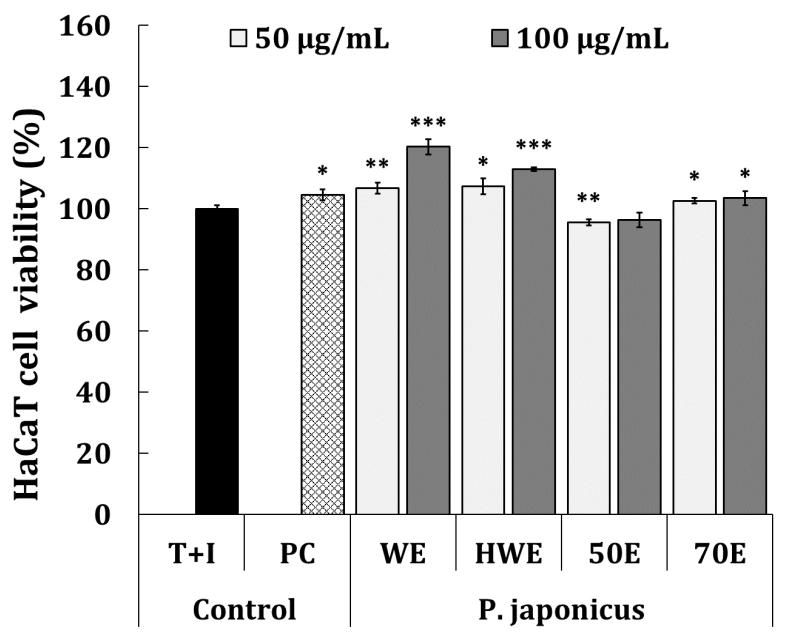

Fig. 1. Cytotoxic effect of solvent extracts from P. japonicus using (A) RAW 264.7 macrophage and (B) HaCaT keratinocyte.

Each sample were treated to RAW 264.7 or HaCaT cells, and inflammation inducer, such as lipopolysaccharide (LPS) or TNF- $\alpha$ and IFN- $\gamma$ (T+I) were subsequently stimulated for $24 \mathrm{~h}$. A dexamethasone ( 50 and $20 \mu \mathrm{g} / \mathrm{mL}$, for RAW 264.7 and $\mathrm{HaCaT}$, respectively) was used as positive controls(PC). Results are expressed as mean $\pm \mathrm{SD}$. of three independent test in triplicate. Asterisks mean significant difference between inflammation group (LPS or T+I) and each group by Student's t-test. " $\mathrm{p}<0.05, " \mathrm{p}<0.01, " \mathrm{p}<0.001$. PJ-WE, water extract of $P$. japonicus; PJ-HWE, hot water extract of $P$. japonicus; PJ-50E, 50\% ethanol extract of $P$. japonicus; PJ-70E, 70\% ethanol extract of $P$. japonicus.

위에서 대조군 대비 세포독성을 나타내지 않고, 세포생존율 을 증가시키는 것으로 확인되었으며 머위가 어떠한 작용으 로 세포증식을 유도하는지 추가적인 연구가 필요할 것으로 사료된다.

\section{면역세포를 통한 추출용매 별 머위의 염증억제활성}

마우스 유래 대식세포주인 RAW 264.7 세포는 선천면역조 절 세포로서 면역 조절의 1 차적인 역할을 담당하고 있으며 조 직 및 세포 손상뿐만 아니라 염증반응에 핵심적인 역할을 하 는 세포로 알려져 있다(Oishi와 Manabe, 2018). LPS로 염증 모델을 형성하고 시료처리에 의해 생성되는 염증 매개 인자인 IL-6 및 NO의 생성량을 평가함으로써 염증억제 활성을 평가 하고자 하였다. 시료처리에 의한 IL-6 억제 활성 평가는 Fig. 2(A)에 나타냈으며, $50-100 \mu \mathrm{g} / \mathrm{mL}$ 의 농도범위에서 평가되었 다. 양성대조군(positive control, PC)으로 이용된 dexamethasone $(50 \mu \mathrm{g} / \mathrm{mL})$ 은 LPS 유도군 $(12.1 \mathrm{ng} / \mathrm{mL})$ 대비 $6.4 \mathrm{ng} / \mathrm{mL}$ (49.3\%)의 통계적으로 유의한 IL-6 억제활성이 나타났다. 머 위 추출물 4종 중 PJ-HWE 및 PJ-50E 처리군은 상기 농도범 위에서 LPS 유도군 대비 통계적으로 유의한 IL-6 억제활성 은 확인되지 않았으며, PJ-70E 처리군의 경우 $8.2-9.9 \mathrm{ng} / \mathrm{mL}$ (19.1-34.1\%)의 통계적으로 유의한 IL-6 억제활성을 나타냈 다. 또한, PJ-WE 처리군의 경우 동일 농도범위에서 LPS 유 도군 대비 4.7-7.9 ng/mL(36.3-63.9\%)의 우수한 IL-6 억제활 성이 확인되었으며, 특히 $100 \mu \mathrm{g} / \mathrm{mL}$ 의 농도에서는 PC 대조
군보다 우수한 활성을 나타냈다. 다음으로 $\mathrm{NO}$ 억제활성의 결과는 Fig. 2(B)에 나타냈다. PC 대조군으로 이용된 L-NGnitroarginine methyl ester(L-NAME; $50 \mu \mathrm{g} / \mathrm{mL}$ )는 LPS 유도 군 $(47.2 \mu \mathrm{M})$ 대비 $22.3 \mu \mathrm{M}(52.7 \%)$ 의 통계적으로 유의한 $\mathrm{NO}$ 억제활성이 확인되었다. 머위 추출물 4종 중 PJ-HW 처 리군은 50-100 $\mu \mathrm{g} / \mathrm{mL}$ 의 농도범위에서 LPS 유도군 대비 통 계적으로 유의한 억제활성은 확인되지 않았다. 반면, $\mathrm{PJ}-70 \mathrm{E}$ 처리군의 경우 $35.7-35.8 \mu \mathrm{M}(24.1-24.4 \%)$ 의 유의한 $\mathrm{NO}$ 억 제활성을 나타냈으며, PJ-50E는 29.9-34.6 $\mu \mathrm{M}(26.7-36.6 \%)$ 의 농도-의존적인 $\mathrm{NO}$ 억제활성이 확인되었다. 한편, $\mathrm{PJ}-\mathrm{WE}$ 처리군은 $50-100 \mu \mathrm{g} / \mathrm{mL}$ 의 농도범위에서 $24.5-30.4 \mathrm{ng} / \mathrm{mL}$ (35.5-48.0\%)의 통계적으로 유의한 $\mathrm{NO}$ 억제활성을 나타냈 으며, PC 대조군으로 이용된 L-NAME와 유사한 억제활성을 보였다. Lee 등(2019)의 연구에서 머위 추출물 유래의 lignin (petasitesin A) 처리를 통해 LPS로 염증이 유발된 RAW 264.7 세포에서 NO 및 prostaglandin E의 inhibitory half concentration(IC 50) 값이 각각 $15 \pm 1.4$ 및 $17 \pm 3.2$ 로 보였고, 이와 관련된 inducible nitric oxide synthase(iNOS) 및 cyclooxygenase-2(COX-2)의 발현량이 감소하는 것으로 확 인되었으며, 본 연구와 유사한 경향으로 판단되었다. 연구결 과를 종합해보면, 4종의 시료 중 PJ-WE가 RAW 264.7 세포 에서 가장 우수한 IL-6 및 NO 억제활성을 나타내는 것으로 확인되었으며, 추후 어떤 기작을 통해 억제활성이 나타나는 지에 대한 연구가 필요할 것으로 사료된다. 
(A)

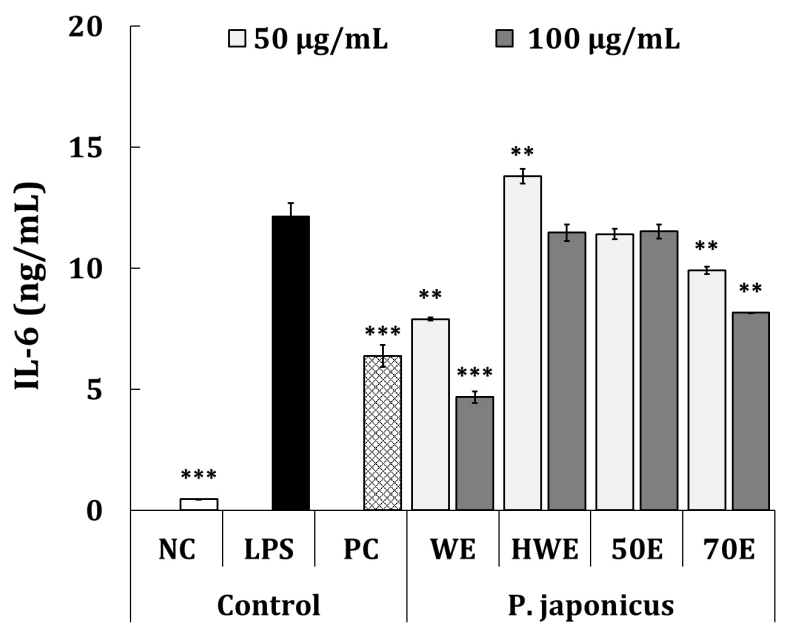

(B)

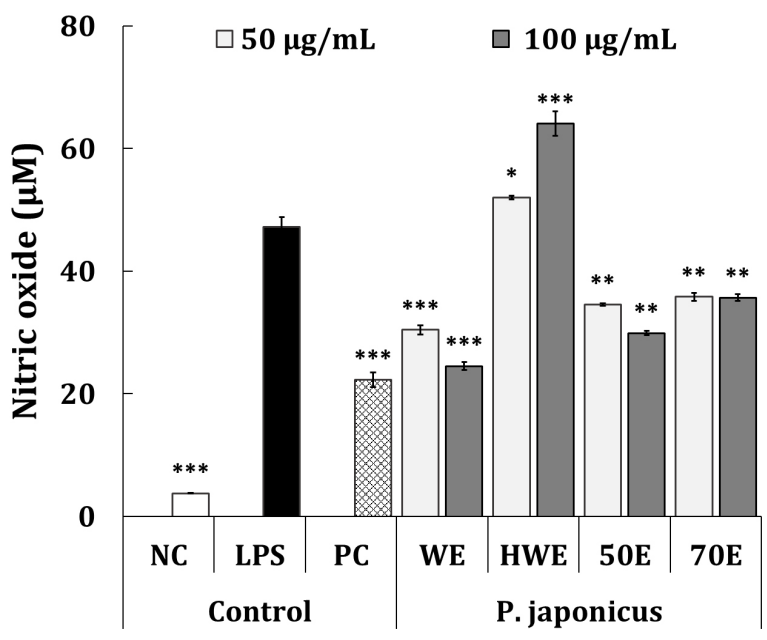

Fig. 2. Anti-inflammatory activities of solvent extracts from $P$. japonicus on LPS-stimulated RAW 264.7 cell line.

RAW 264.7 cells were treated with sample followed by LPS treatment for $24 \mathrm{~h}$, and production of (A) IL-6 and (B) nitric oxide (NO) were estimated. A dexamethasone $(50 \mu \mathrm{g} / \mathrm{mL}$ ) or N-nitroarginine methyl ester (L-NAME; $50 \mu \mathrm{g} / \mathrm{mL}$ ) were used as positive control (PC) for IL-6, or NO experiments, respectively. Results are expressed as mean $\pm \mathrm{SD}$. of three independent test in triplicate. Asterisks mean significant difference between LPS group and each group by Student's t-test. ${ }^{*} \mathrm{p}<0.05,{ }^{* *} \mathrm{p}<0.01,{ }^{* * *} \mathrm{p}<0.001$. PJ-WE, water extract of $P$. japonicus; PJ-HWE, hot water extract of $P$. japonicus; PJ-50E, 50\% ethanol extract of P. japonicus; PJ-70E, 70\% ethanol extract of $P$. japonicus.

\section{피부세포를 통한 추출용매 별 머위의 염증억제활성}

TNF- $\alpha$ 및 IFN- $\gamma(\mathrm{T}+\mathrm{I})$ 유도에 의해 염증이 유발된 $\mathrm{HaCaT}$ 세포는 cyclooxygenase-2(COX-2) 및 IL-6 등을 생성하여 아 토피 및 피부염을 유발하는 것으로 알려져 있다(Lee 등, 2020). 본 연구에서는 이를 적용하여 피부세포에 염증성 사이토카인 인 TNF- $\alpha$ 및 IFN- $\gamma(\mathrm{T}+\mathrm{I})$ 을 처리하고 세포가 분비하는 사이 토카인의 생성량을 통해 피부염 억제활성을 평가하고자 하였 다. 먼저, IL-6 억제활성 평가는 Fig. 3(A)에 나타냈으며, PC 대조군으로 이용된 dexamethasone $(20 \mu \mathrm{g} / \mathrm{mL})$ 은 $\mathrm{T}+\mathrm{I}$ 유도군 $(1,865.0 \mathrm{pg} / \mathrm{mL})$ 대비 $781.9 \mathrm{pg} / \mathrm{mL}(59.6 \%)$ 의 통계적으로 유 의한 IL-6 억제활성을 나타냈다. PJ-70E 처리군의 경우, $50-100 \mu \mathrm{g} / \mathrm{mL}$ 의 농도범위에서 통계적으로 유의한 IL-6 억제 활성은 확인되지 않았지만 PJ-50E 처리군은 $100 \mu \mathrm{g} / \mathrm{mL}$ 의 농도에서 $1,093.8 \mathrm{pg} / \mathrm{mL}(42.4 \%)$ 의 통계적으로 유의한 억제 활성을 나타냈다. 한편, PJ-HWE 처리군의 경우 $50-100 \mu \mathrm{g} / \mathrm{mL}$ 의 농도범위에서 $\mathrm{T}+\mathrm{I}$ 유도군 대비 $464.1-952.7 \mathrm{pg} / \mathrm{mL}$ (50.2-77.0\%)의 통계적으로 유의한 IL-6 억제활성을 나타냈 으며, PJ-WE 처리군의 경우 동일 농도범위에서 583.9-561.9 $\mathrm{pg} / \mathrm{mL}(70.5-71.7 \%)$ 의 유의한 억제활성을 나타냈다. PJ-HWE 와 PJ-WE를 비교해 볼 때, 저농도인 $50 \mu \mathrm{g} / \mathrm{mL}$ 에서는 PJ$\mathrm{WE}$ 가 우수한 것으로 확인되었지만, 고농도인 $100 \mu \mathrm{g} / \mathrm{mL}$ 의 농도에서는 $\mathrm{PJ}-\mathrm{HWE}$ 가 비교적 우수한 것으로 확인되었다. IL-8 억제활성은 Fig. 3(B)에 나타냈다. PC 대조군으로 이용 된 dexamethasone $(20 \mu \mathrm{g} / \mathrm{mL})$ 은 $\mathrm{T}+\mathrm{I}$ 유도군 $(1,960.1 \mathrm{pg} / \mathrm{mL})$
대비 $916.2 \mathrm{pg} / \mathrm{mL}(53.6 \%)$ 로 통계적으로 유의한 IL-8 억제활 성을 나타냈다. 머위 추출물 4종은 $50-100 \mu \mathrm{g} / \mathrm{mL}$ 의 농도범 위에서 $\mathrm{T}+\mathrm{I}$ 유도군 대비 농도-의존적 유의한 IL-8 억제활성 이 확인되었으며, $\mathrm{PJ}-70 \mathrm{E}$ 처리군의 경우 상기 농도범위에서 $1,138.7-1,623.3 \mathrm{pg} / \mathrm{mL}(17.3-42.1 \%)$ 의 IL-8 억제활성을 나타 냈다. PJ-50E 처리군은 T+I 유도군 대비 $324.9-943.6 \mathrm{pg} / \mathrm{mL}$ (52.1-83.9\%)의 IL-8 억제활성을 나타냈으며, PJ-HWE 처리 군의 경우 $103.3-542.2 \mathrm{pg} / \mathrm{mL}(72.7-95.3 \%)$ 의 통계적으로 유 의한 억제활성이 확인되었다. 한편, $\mathrm{PJ}-\mathrm{WE}$ 처리군의 경우 $50-100 \mu \mathrm{g} / \mathrm{mL}$ 의 농도범위에서 추출물 4종 중 $\mathrm{T}+\mathrm{I}$ 유도군 대비 가장 우수한 활성(59.3-412.3 pg/mL; 79.4-97.5\%)을 나타냈다. $\mathrm{Kim}$ 등(2017)의 연구에서 동일 세포주를 이용하여 cadmium으 로 손상을 유도시킨 후, 머위 추출물을 이용하여 세포보호 효 과를 확인한 바 있으며, 본 연구와 비교해 볼 때 머위 추출물 이 피부 개선에 긍정적인 역할을 할 것으로 판단되었다. 본 연구결과를 종합해 볼 때, 두 세포주를 이용한 염증억제활성 평가에서 머위 추출물 4종 중 PJ-WE가 우수한 활성을 나타 냈으며, 염증관련 기능성 소재로서 활용 가능할 수 있을 것으 로 사료된다.

\section{요 약}

머위의 일반성분, 무기질과 서로 다른 용매로 추출한 머위 의 항산화 효과, 혈당강하능 및 항염증 활성을 알아보았다. 
(A)

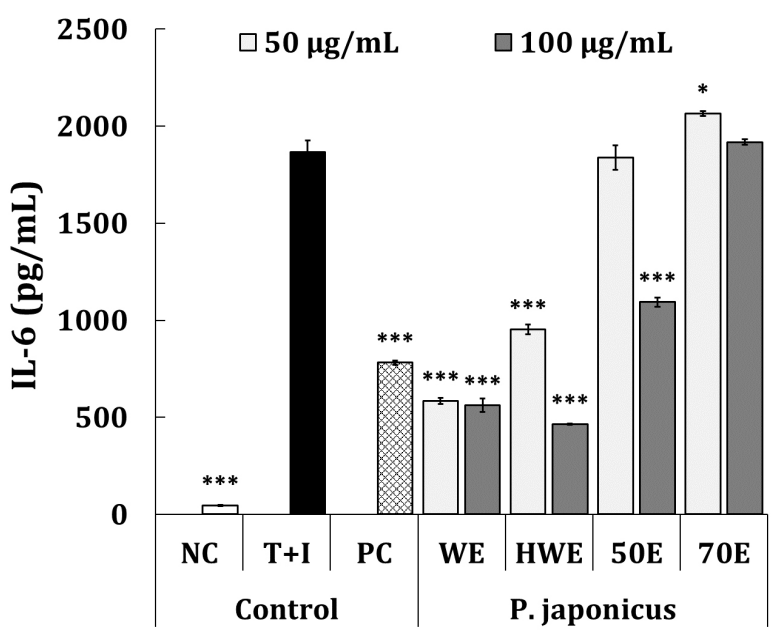

(B)

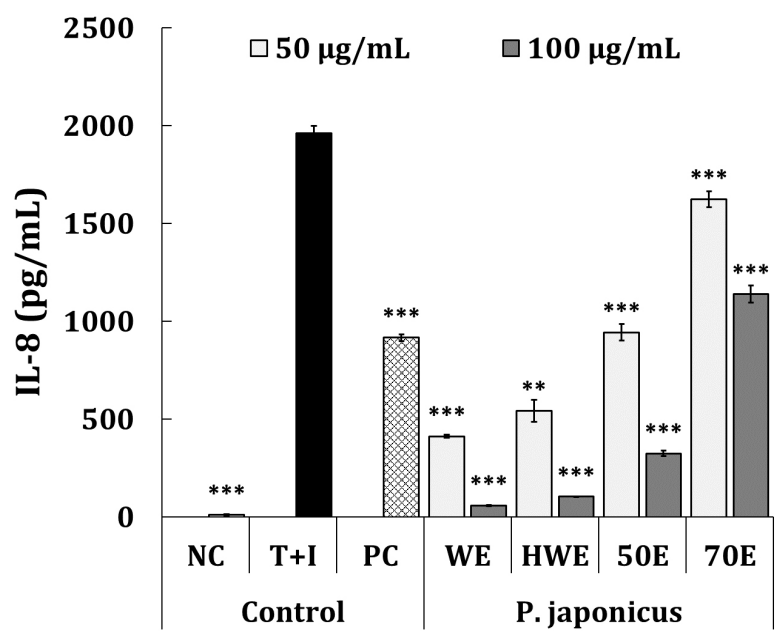

Fig. 3. Anti-inflammatory activities of solvent extracts from $P$. japonicus on $\mathrm{TNF}-\alpha+\mathrm{IFN}-\gamma(\mathrm{T}+\mathrm{I})$-stimulated HaCaT keratinocyte.

$\mathrm{HaCaT}$ keratinocyte were treated with each sample followed by TNF- $\alpha+\mathrm{IFN}-\gamma(\mathrm{T}+\mathrm{I})$ treatment for $24 \mathrm{~h}$, and the production of (A) IL-6 and (B) IL-8 were estimated. A dexamethasone $(20 \mu \mathrm{g} / \mathrm{mL})$ were used as positive control (PC). Results are expressed as mean $\pm \mathrm{SD}$. of three independent test in triplicate. Asterisks mean significant difference between T+I group and each group by Student's t-test. ${ }^{*} \mathrm{p}<0.05,{ }^{* *} \mathrm{p}<0.01,{ }^{* * *} \mathrm{p}<0.001$. PJ-WE, water extract of $P$. japonicus; PJ-HWE, hot water extract of $P$. japonicus; PJ-50E, 50\% ethanol extract of $P$. japonicus; PJ-70E, 70\% ethanol extract of $P$. japonicus.

동결건조한 머위의 수분함량은 $6.61 \%$, 조지방 $4.51 \%$, 조단 백질 $23.75 \%$, 조회분 $18.62 \%$, 탄수화물 $46.97 \%$ 및 조섬유 $39.22 \%$ 로 검출되었고, 무기질 중에서는 특히 $\mathrm{K}$ 의 함량이 높 아 좋은 식품 소재라 할 수 있었다. 서로 다른 용매로 추출한 머위의 총폴리페놀 및 항산화 활성은 에탄올로 추출한 시료 (PJ-50E 및 PJ-70E)가 높은 값을 나타냈으며, 물로 추출한 시 료(PJ-WE)가 유의적으로 가장 낮은 함량을 나타냈다. 하지 만 $\alpha$-glucosidase 저해활성은 반대의 결과로 물로 추출한 시 료에서 높은 저해활성을 나타냈고, 에탄올로 추출한 경우는 활성이 전혀 나타나지 않았다. RAW 264.7 및 $\mathrm{HaCaT}$ 세포 를 이용해 시료 처리에 따른 세포독성 평가를 진행한 결과, $50-100 \mu \mathrm{g} / \mathrm{mL}$ 의 농도범위에서 통계적으로 유의한 세포독성 은 확인되지 않았다. 염증억제활성 평가 결과, $\mathrm{PJ}-\mathrm{WE}$ 처리군 은 RAW 264.7 세포에서 IL-6 및 산화질소의 억제활성이 우 수한 것으로 판단되었으며, $\mathrm{HaCaT}$ 세포에서 IL-6 및 IL-8의 생성량을 유의적으로 감소시키는 것으로 확인되었다. 따라 서, 항산화활성이 높은 식품 제조를 위해서는 에탄올로 추출 한 것이 좋으나, $\alpha$-glucosidase 저해활성 및 높은 염증억제활 성을 나타낸 물로 추출하는 것이 기능성 식품의 이용가능성 을 높일 것으로 기대된다.

\section{감사의 글}

본 연구는 농촌진흥청 공동연구사업(과제번호: PJ01528507) 의 지원에 의해 이루어진 것임.

\section{Conflict of interests}

The authors declare no potential conflict of interest.

\section{ORCID}

Hyun-Ju Eom https://orcid.org/0000-0003-3746-1233 Hyun Young Shin https://orcid.org/0000-0001-9196-0434 Kwang-Won Yu https://orcid.org/0000-0001-5285-7303

\section{References}

Ahn EM, Asamenew G, Kim HW, Lee SH, Yoo SM, Cho SM, Cha YS, Kang MS. Anti-obesity effects of Petasites japonicus (Meowi) ethanol extract on RAW 264.7 macrophages and 3T3-L1 adipocytes and its characterization of polyphenolic compounds. Nutrients, 12, 1261 (2020)

Ahn H, Chung L, Choe E. In vitro antioxidant activity and $\alpha$-glucosidase and pancreatic lipase inhibitory activities of several Korean Sanchae. Korean J Food Sci Technol, 47, 164-169 (2015)

AOAC. Official Methods of Analysis. 13th ed, Association of Official Analytical Chemists, Arlington, VA, USA, $p$ 342 (1990) 
Cho BS, Lee JJ, Ha JO, Lee MY. Physicochemical composition of Petasites japonicus S. et Z. Max.. Korean J Food Preserv, 13, 661-667 (2006)

Choi HW, Sim KH. Antioxidant activities and quality characteristics of rice cookie with added butterbur (Petasites japonicus) powder. Korean J Food Nutr, 34, 1-14 (2021)

Choi Y, Kim MH, Shin JJ, Park JM, Lee JS. The antioxidant activities of the some commercial teas. J Korean Soc Food Sci Nutr, 32, 723-727 (2003)

Choi Y, Lee SM, Chun J, Lee HB, Lee J. Influence of heat treatment on the antioxidant activities and polyphenolic compounds of Shiitake (Lentinus edodes) mushroom. Food Chem, 99, 381-387 (2006)

Choi YW, Lee KP, Kim JM, Kang S, Park SJ, Lee JM, Moon HR, Jung JH, Lee YG, Im DS. Petatewalide B, a novel compound from Petasites japonicus with antiallergic activity. J Ethnopharmacol, 178, 17-24 (2016)

Eom HJ, Shin HY, Ji YM, Kwon NR, Yoon HS, Kim IJ, Song YS, Yu KW. Nutritional components and physiological activity of Centella asiatica cultured in Chungju by drying method. Korean J Food Nutr, 34, 165-173 (2021)

Hiemori-Kondo M, Nii M. In vitro and in vivo evaluation of antioxidant activity of Petasites japonicus Maxim. flower buds extracts. Biosci Biotechnol Biochem, 84, 621-632 (2020)

Hwang EY, Kim DH, Kim HJ, Hwnag JY, Park TS, Lee IS, Son JH. Antioxidant activities and nitric oxide production of medicine plants in Gyeongsangbukdo (Carthamus tinctorius seed, Cyperus rotundus, Schizonepeta tenuifolia, Polygonatum odoratum var. pluriflorum, Paeonia lactiflora). J Appl Biol Chem, 54, 171-177 (2011)

Jang GY, Kim HY, Lee SH, Kang Y, Hwang IG, Woo KS, Kang TS, Lee J, Jeong HS. Effects of heat treatment and extraction method on antioxidant activity of several medicinal plants. J Korean Soc Food Sci Nutr, 41, 914920 (2012)

Jeong HJ. Optimization mixture ratio of Petasites japonicus, Luffa cylindrica and Houttuynia cordata to develop a functional drink by mixture design. MS Thesis, Pusan University, Korea, p 1-4 (2016)

Jiang GH, Na MO, Eun JB. Physicochemical characteristics and sensory evaluation of bracken (Pteridium aquilinum) and Aster scaber dried by different methods. Korean J Food Preserv, 23, 819-824 (2016)

Kim BA. Cytoprotective effect of Petasites japonicus extract on cadmium-induced cytotoxicity in HaCaT cell. J Soc Cosmet Sci Korea, 43, 87-92 (2017)

Kim EJ, Choi JY, Yu MR, Kim MY, Lee SH, Lee BH. Total polyphenols, total flavonoid contents, and antioxidant activity of Korean natural and medicinal plants. Korean J Food Sci Technol, 44, 337-342 (2012)

Kim EJ, Kim HN, Kim HM, Park SS. Anti-inflammatory activities of hot water extracts of Petasites japonicus leaves in LPS-stimulated RAW 264.7 cells. J Korean Soc Food Sci Nutr, 49, 289-294 (2020)

Kim JH, Na Y, Sim GS, Lee BC, Pyo HB. Antioxidative and anti-inflammatory effects of Petasites japonicus. J Soc Cosmet Scientists Korea, 32, 263-267 (2006)

Kim MY, Yi JH, Hwang YY, Song KS, Jun MR. Isolation and identification of antioxidant substances from the stems of butterbur (Petasites japonicus). J Korean Soc Food Sci Nutr, 37, 979-984 (2008)

Lee DW, Lee SY, Chung HS, Choi YW, Im DS, Lee YG. Optimization of a process for extraction of petasin from Petasites japonicus leaves by response surface methodology. J Life Sci, 23, 1360-1364 (2013)

Lee JS, Jeong MR, Park SS, Ryu SM, Lee J, Song Z, Guo Y, Choi JH, Lee DH, Jang DS. Chemical constituents of the leaves of butterbur (Petasites japonicus) and their anti-inflammatory effects. Biomolecules, 9, 806-816 (2019)

Lee KH. Antioxidative activity of butterbur extracts and quality characteristics of butterbur noodles. MS Thesis, Sookmyung Women's University, Korea, p 1-11 (2011)

Lee KP, Kang S, Park SJ, Choi YW, Lee YG, Im DS. Anti-allergic and anti-inflammatory effects of bakkenolide B isolated from Petasites japonicus leaves. J Ethnopharmacol, 148, 890-894 (2013)

Lee SY, Choi SY, Han HM, Yoo SM, Choi MJ. Effect of blanching conditions and thawing methods on the quality properties of butterbur stem. Food Eng Prog, 19, 226-234 (2015)

Lee SY, Kim JH, Park JM, Lee IC, Lee JY. Antioxidant activity and inhibition activity against $\alpha$-amylase and $\alpha$ glucosidase of Smilax china L. Korean J Food Preserv, 
21, 254-263 (2014)

Lee SY. Analysis of contents and development of reduction method of toxic pyrrolizidine alkaloids from Petasites japonicus. MS Thesis, Pusan University, Korea, p 1-4 (2013)

Lee Y, Choi HK, N'Deh KPU, Choi YJ, Fan M, Kim EK, Chung KH, An JH. Inhibitory effect of Centella asiatica extract on DNCB-induced atopic dermatitis in HaCaT cells and BALB/c mice. Nutrients, 12, 411-427 (2020)

Lee YM, Bae JH, Jung HY, Kim JH, Park DS. Antioxidant activity in water and methanol extracts from Korean edible wild plants. J Korean Soc Food Sci Nutr, 40, 29-36 (2011)

Lim JH, Kim BK, Park CE, Park KJ, Kim JC, Jeong JW, Jeong SW. Antioxidant and antimicrobial activities of persimmon leaf tea and green tea. J East Asian Soc Dietary Life, 18, 797-804 (2008)

Lopez-Garcia J, Lehocky M, Humpolicek P, Saha P. HaCaT keratinocyte response on antimicrobial atelocollagen substrates: Extent of cytotoxicity, cell viability and proliferation. J Funct Biomater, 5, 43-57 (2014)

Manach C, Scalbert A, Morand C, Rémésy C, Jime'nez L. Polyphenols: Food sources and bioavailability. Am J Clin Nutr, 79, 727-747 (2004)

Oh SH, Yang YH, Kwan OY, Kim MR. Effects of diet with added Butterbur (Petasites japonicus Maxim) on the plasma lipid profiles and antioxidant index of mice. $\mathrm{J}$ East Asian Soc Dietary Life, 16, 399-407 (2006)

Oishi Y, Manabe I. Macrophages in inflammation, repair and regeneration. Int Immunol, 30, 511-528 (2018) Osborne DR, Voogt P. The Analysis of Nutrients in Foods.
London Academic Press, London, UK. p 130-134 (1981) Seo HS, Jeong BH, Cho YG. The antioxidant and anticancer effects of butterbur (Petasites japonicus) extracts. Korean J Plant Res, 21, 265-269 (2008)

Sim WS, Lee JS, Lee SR, Choi SI, Cho BY, Choi SH, Han X, Jang GW, Kwon HY, Choi YE, Kim JY, Kim JD, Lee OK. Antioxidant effect of extracts from 9 species of forest plants in Korea. J Food Hyg Saf, 34, 404-411 (2019)

Song BH, Whang SH, Lee JD, Kim HJ, Chung HR, Moon HK. A study on the mineral contents of Korean common foods and analytical methods. 2 Potassium. Kor J Food Hygiene, 7, 37-44 (1992)

Standl E, Baumgartl HJ, Fuchtenbusch M, Stemplinger J. Effect of acarbose on additional insulin therapy in type 2 diabetic patients with late failure of sulphonylurea therapy. Diabetes Obes Metab, 1, 215-220 (1999)

Thomet OA, Wiesmann UN, Blaser K, Simon HU. Differential inhibition of inflammatory effector functions by petasin, isopetasin and neopetasin in human eosinophils. Clin Exp Allergy, 31, 1310-1320 (2001)

Tibbot BK, Skadsen RW. Molecular cloning and characterization of a gibberellin-inducible, putative $\alpha$ glucosidase gene from barley. Plant Mol Biol, 30, 229-241 (1996)

Urquiaga I, Leighton F. Plant polyphenol antioxidants and oxidative stress. Biol Res, 33, 55-64 (2000)

Wang Q, Lee AY, Choi JM, Lee DG, Kim HY, Lee S, Cho EJ. In vitro radical scavenging effect and neuroprotective activity from oxidative stress of Petasites japonicus. Kor J Pharmacogn, 45, 147-153 (2014) 